\title{
Is Contingent Valuation Worth the Trouble?
}

\author{
John M. Heyde $\dagger$
}

Since Congress enacted the Comprehensive Environmental Response, Compensation and Liability Act of 1980 ("CERCLA"), the federal government has taken an aggressive stance toward individuals and companies that release hazardous substances into the environment. CERCLA and subsequent statutes, such as the Clean Water Act ${ }^{2}$ and the Oil Pollution Act of $1990,{ }^{3}$ gave federal and state governments extensive powers to recover the costs of responding to environmental contamination and cleaning up contaminated areas. In addition, these statutes gave governments-as trustees for publicly owned natural resources-authority to sue polluters for damages to those resources. ${ }^{4}$

But is it possible to put a price tag on the damage a release does to a publicly owned and widely used natural resource? These resources-including parks, rivers, protected forests, and shorelines-are not bought and sold on the open market. Moreover, the governments that administer them do not charge the public the true market price for enjoying them. As a result, courts administering environmental cleanup statutes lack access to traditional means of measuring economic or property damage. To some degree, courts can use economic studies to calculate the value resource users lose to contamination; for example, an

$\dagger$ A.B. 1988, Harvard University; J.D. Candidate 1995, The University of Chicago.

1 Pub L No 96-510, 94 Stat 2767 (1980), amended by The Superfund Amendments and Reauthorization Act of 1986, Pub L No 99-499, 100 Stat 1613 (1986), codified at 42 USC $\S$ 9601-75 (1988 \& Supp 1992).

2 Federal Water Pollution Control Act Amendments of 1972 ("Clean Water Act"), 33 USC $\S \$ 1251$ et seq (1988 \& Supp 1993).

33 USC $\S \S 2701-61$ (Supp 1993).

4 CERCLA, 42 USC § 9607(f); Clean Water Act, 33 USC § 1321(f)(4)-(5); Oil Pollution Act of 1990, 33 USC $\S \S 2702,2706$. Other statutes also have given government trustees this authority. See Outer Continental Shelf Lands Act Amendments of 1978, 43 USC $\S 1813(\mathrm{a})$-(b) (1988), repealed by Oil Pollution Act of $1990 \S 2004$, Pub L No 101-380, 104 Stat 484, 507; Deepwater Port Act of 1974, 33 USC $\S 1517$ (d) (1988), repealed by Oil Pollution Act of 1990 \$ 2003(a)(2), 104 Stat at 507; Trans-Alaska Pipeline Authorization Act, 43 USC \& 1653(a)(1), (c)(1) (1988 \& Supp 1992). Finally, a number of states also have statutes providing this authority. See Frank B. Cross, Natural Resource Damage Valuation, 42 Vand L Rev 269, 277-80 (1989). 
estimate of the amount anglers spend each year on trips to a pristine fishing area might approximate the value anglers would lose if the fishing area became contaminated. Unfortunately, in many cases, even these methods are unavailable. Moreover, courts have come to recognize that society derives value from natural resources not only by using the resources, but also from "nonuse" sources such as merely knowing the resource exists." How can courts quantify these nonuse values?

Enter contingent valuation, a controversial survey technique used to establish both "use" and "nonuse" values. In a contingent valuation study, a surveyor asks "affected" people how much they would pay to prevent contamination of a natural resource, or alternatively, how much they would demand to accept the contamination. ${ }^{6}$ The surveyor then aggregates the per-person results to arrive at a total damages value. ${ }^{7}$ Proponents have hailed contingent valuation as the only method available to compensate the public fully for environmental degradation and to give potential polluters the proper incentives to avoid hazardous-substance releases. ${ }^{8}$ Critics, however, have charged that contingent valuation provides biased and wildly variable results that will lead to unfair liability burdens and excess incentives to avoid pollution. ${ }^{9}$

${ }^{5}$ See, for example, Puerto Rico v SS Zoe Colocotroni, 628 F2d 652, 673-74 (1st Cir 1980); Ohio v United States Department of the Interior, 880 F2d 432, 462-64 (DC Cir 1989); Idaho $v$ Southern Refrigerated Transport Inc., 1991 US Dist LEXIS 1869, *54 (D Idaho).

- See Robert Cameron Mitchell and Richard T. Carson, Using Surveys to Value 'Public Goods: The Contingent Valuation Method 2 (Resources for the Future, 1989); Kevin M. Ward and John W. Duffield, Natural Resource Damages: Law and Economics § 12.1 at 282-83 (John Wiley \& Sons, 1992); Cross, 42 Vand L Rev at 315-20 (cited in note 4). See also text accompanying notes $46-47,77-85$.

7 Mitchell and Carson, Using Surveys to Value Public Goods at 41 . One difficulty with contingent valuation is deciding how many people's attitudes are relevant when valuing a particular resource. See Ward and Duffield, Natural Resource Damages $\$ 12.3$ at 284-85.

${ }^{8}$ See, for example, Cross, 42 Vand L Rev at 320 (cited in note 4) ("In many instances, contingent valuation provides the best method for assessing the complete economic value that individuals place on natural resource preservation."); Raymond J. Kopp, Paul R. Portney, and V. Kerry Smith, Natural Resource Damages: The Economics Have Shifted After Ohio v. United States Department of the Interior, 20 Envir L Rptr 10127, 10130 (1990) ("CC]ontingent valuation techniques are the only way known to measure [] nonuse damages."). But see Frank B. Cross, Restoring Restoration for Natural Resource Damages, 24 U Toledo L Rev 319, 332-33 (1993) (arguing that "problems . . of contingent valuation counsel strongly against its generalized use"). Cross argues in both articles that the best general solution is to require polluters to pay the cost of restoring a damaged resource. 42 Vand L Rev at 273 (cited in note 4); 24 U Toledo L Rev at 343-44.

${ }^{9}$ See, for example, Note, "Ask a Silly Question ...": Contingent Valuation of Natural 
After setting out this problem in Section I, this Comment argues in Section II that efforts to improve the technique of contingent valuation are wasted because the method's shortcomings are more fundamental than mere statistical error. Courts and natural resource trustees should abandon contingent valuation not because it gives bad estimates, but because it would not be worth the cost of developing and litigating contingent valuation studies even if the studies were completely accurate. The Comment suggests that obsession with the "perfect" damages figure tends to commodify our understanding of natural resources, thereby undermining the proper relationship that society should have with these resources. As a result, even if contingent valuation yielded fully accurate measurements of a natural resource's noneconomic value, it should nonetheless be abandoned in favor of simpler, although less accurate, "rules of thumb."

Section III then describes three possible rules of thumb that might be both more cost-effective and less commodifying than contingent valuation: (1) charging the polluter the cost of restoration, even if a contingent valuation study would suggest that restoration is not worth the cost; (2) charging the polluter some fixed multiplier of the damages that can be measured through traditional means, ${ }^{10}$ or (3) developing, by statute or regulation, a matrix that yields a damages figure based on the variables that a regulatory body finds relevant to environmental damage. ${ }^{11}$ Section III also explores the extent to which courts possess the authority to begin using these alternatives as well as the extent to which Congress can legislate these alternatives as it considers reauthorizing CERCLA. ${ }^{12}$ The Comment concludes that either a damages multiplier or a damages matrix offers the best resolution of the problems associated with accuracy in measurement,

Resource Damages, 105 Harv L Rev 1981, 1990-93 (1992).

10 This method is analogous to "treble damages" in antitrust law. See text accompanying notes 132-36.

11 This method is somewhat analogous to the approach used in workers' compensation statutes. See text accompanying note 144 .

${ }_{12}$ Although CERCLA was due to be reauthorized in 1994, as of October 1994, reauthorization seemed unlikely. Timothy Noah, Disputes End Revision Effort for Superfund, Wall St J B6 (Oct 6, 1994). During 1994, the Clinton Administration prepared a comprehensive CERCLA reauthorization bill, which Representative Al Swift (D-Wash) introduced in the House, and Senator Max Baucus (D-Mont) introduced in the Senate, in February 1994. HR 3800, 103d Cong, 2d Sess (Feb 3, 1994), in 140 Cong Rec H287 (Feb 3, 1994); S 1834, 103d Cong, 2d Sess (Feb 7, 1994), in 140 Cong Rec S1047, S1058 (Feb 7, 1994). 
ease of measurement, and respect for the nonmonetizable aspects of unique natural resources.

\section{CONTINGENT VALUATION AND THE CURRENT NATURAL RESOURCE DAMAGES SCHEME}

\section{A. General Structure of Natural Resource Damages Recovery}

Responding to problems with traditional liability actions, ${ }^{13}$ Congress supplanted the common law structure with a series of statutes that allow the federal government to force cleanups at contaminated sites and charge the cost to polluters. The archetype of these statutes is CERCLA. CERCLA allows the government or private parties to sue polluters to recover the costs of responding to an incident of environmental contamination. ${ }^{14}$ The definition of a polluter (called a "covered person" under CERCLA) is broad, encompassing nearly anyone with a connection to a contaminated site, including current and former owners and operators, generators of any hazardous substances, and transporters who carried any hazardous substances to the site. ${ }^{15}$ All of these parties face strict and, usually, joint and several liability. ${ }^{16}$

However, even if a polluter is fully liable for the cost of restoring a contaminated natural resource, the public is still not made whole. First, restoration is never immediate, and the public loses some of the resource's value for the period between the contamination and the restoration. Second, some damage can never be repaired. As a result, Congress began including provisions in environmental statutes to allow government trustees to recover nonuse damages to natural resources in addition to recovering the costs of responding to a contamination incident or restoring a damaged resource. Congress first included the natural resource damages concept in the Trans-Alaska Pipeline Authori-

13 These problems include practical difficulties in proving causation or managing large numbers of defendants, see Warren Freedman, Hazardous Waste Liability 113-14 (BNA, 1992), as well as substantive problems for government plaintiffs, such as rules limiting recovery to damages to wildlife or navigable waters. Cross, 42 Vand L Rev at 278 n 41 (cited in note 4).

1442 USC \& 9607(a). For a more extensive description of the CERCLA cost recovery action, see Comment, When Less is More: A Significant Risk Threshold for CERCLA Liability, 60 U Chi L Rev 697, 699-701 (1993).

1542 USC \$ 9607(a).

16 Comment, $60 \mathrm{U}$ Chi L Rev at 701. 
zation Act of 1973 and the Deepwater Port Act of $1974 .{ }^{17}$ Since then, Congress has included natural resource damages provisions in the Outer Continental Shelf Lands Act Amendments of 1978, CERCLA, the Oil Pollution Act of 1990, and the amendments to the Clean Water Act. ${ }^{18}$

CERCLA provides a good example of how these provisions work. CERCLA's $\$ 107$ authorizes the President and each state governor to designate federal and state officials as "trustees" for natural resources. ${ }^{19}$ Section 107 then allows the trustees to recover "damages for injury to, destruction of, or loss of natural resources, including the reasonable costs of assessing such injury, destruction, or loss resulting from" a hazardous-substance release. ${ }^{20}$ Any party liable for cleanup costs is also liable for natural resource damages. ${ }^{21}$ Recognizing that courts would face difficulty in valuing the damage done to natural resources, Congress required the President to issue regulations for valuing those damages. ${ }^{22}$ Not only do the regulations convey to trustees and courts the President's opinion of the "best" way to value damages, but they also have evidentiary force in court: any assessment conducted under the regulations carries a "rebuttable presumption" of accuracy. ${ }^{23}$

After calculating the damaged resource's loss in value, trustees use the results in two ways. First, they use the assessment to calculate either the loss pending full restoration of a resource or the permanent loss that occurs when a resource cannot be restored. ${ }^{24}$ Second, they use the calculations to decide whether to restore a resource, by asking whether the permanent loss in val-

17 Trans-Alaska Pipeline Authorization Act $\$ 204(a)(1),(c)(1)$, Pub L No 93-153, 87 Stat 576, 586-87 (1973), codified at 43 USC $\$ 1653(a)(1)$, (c)(1); Deepwater Port Act of $1974 \S 18(\mathrm{~d})$, Pub L No 93-627, 88 Stat 2126, 2142, codified at 33 USC $\S 1517(\mathrm{~d})$, repealed by Oil Pollution Act of 1990 \& 2003(a)(2), 104 Stat at 507.

${ }^{18}$ Outer Continental Shelf Lands Act Amendments of 1978 \$ 303(a)-(b), Pub L No 95372, 92 Stat 629, 674-75, codified at 43 USC $\S 1813(\mathrm{a})$-(b) (1988), repealed by Oil Pollution Act of 1990 § 2004, 104 Stat at 507; CERCLA, 42 USC § 9607(f)(1); Oil Pollution Act of 1990, 33 USC § 2702(a); Clean Water Act of 1977 \$ 58, Pub L No 95-217, 91 Stat 1566, 1596, codified at 33 USC $\$ 1321(f)(4)-(5)$.

1942 USC $\$ 9607(\mathrm{f})$.

20 Id § 9607(a)(4)(C). "Natural resources" include "land, fish, wildlife, biota, air, water, ground water, drinking water supplies, and other such resources." Id § 9601(16).

${ }^{21}$ Id \$ 9607(a). However, entities are not liable for natural resource damages for hazardous-substance releases that occurred before CERCLA's enactment. Id $\$$ 9607(f)(1).

22 Id \$ 9651(c)(1). The President has delegated this responsibility to the United States Department of the Interior. Exec Order No 12316 \& 8(c)(3), 3 CFR 168, 172 (1981), superseded by Exec Order No 12580 § 11(d), 3 CFR 193, 200 (1987).

2342 USC \$ $9607(\mathrm{f})(2)(\mathrm{C})$.

24 Ward and Duffield, Natural Resource Damages $\$ 7.9$ at $142-43$ (cited in note 6). 
ue from not restoring the resource is less than the cost of restoration. $^{25}$

\section{B. The Problem of Valuing Natural Resources}

The natural resource damages provisions in CERCLA and other laws set out a seemingly ideal and economically efficient mechanism for deterring contamination of natural resources and for compensating society when contamination does occur. In practice, however, despite predictions to the contrary, ${ }^{26}$ the natural resource damages provisions have rarely been used. ${ }^{27}$ The federal government's administrative and financial difficulties in bringing suits may be responsible for the infrequent use of these provisions. ${ }^{28}$ But the lack of aggressive natural resource damages recovery must also be traced to the uncertainty over how to value natural resources.

The few natural resource damages cases filed have drawn attention to this area of law. For instance, Exxon Corporation and the United States and Alaska governments settled the Exxon Valdez oil spill case for $\$ 1.125$ billion, which included $\$ 100$ million in restitution for natural resource damages. ${ }^{29}$ In addition, the settlement allows trustees to seek up to $\$ 100$ million in additional damages if studies show additional natural resource injury. ${ }^{30}$ Other well-publicized cases involve injury to the Acushnet River and New Bedford Harbor in Massachusetts, DDT and PCB contamination in southern California, and waste disposal at the Rocky Mountain Arsenal in Colorado. ${ }^{31}$ Aside from a few highprofile cases, however, polluters have paid little in natural re-

\footnotetext{
25 Id $\$ 7.10$ at 143.

${ }^{26}$ See James L. Nicoll, Jr., Marine Pollution and Natural Resource Damages: The Multi-Million Dollar Damage Award and Beyond, 5 USF Marit L J 323, 345 (1993).

${ }^{27}$ Duane Woodard and Michael R. Hope, Natural Resource Damage Litigation under the Comprehensive Environmental Response, Compensation and Liability Act, 14 Harv Envir L Rev 189, 191-93 (1990).

${ }_{28}$ Anthony R. Chase, Remedying CERCLA's Natural Resource Damages Provision: Incorporation of the Public Trust Doctrine Into Natural Resource Damages Actions, 11 Va Envir L J 353, 371-72 (1992).

29 Id at 370.

30 Id at 371 .

31 Id. See also Bradley M. Marten and Cestjon L. McFarland, Litigating CERCLA Natural Resource Damages Claims, 22 Envir Rptr (BNA) 670, 675-76 n 3 (1991) (citing In re Acushnet River and New Bedford Harbor, 716 F Supp 676 (D Mass 1989); United States $v$ Montrose Chemical Corp., 835 F Supp 534 (C D Cal 1993) (DDT and PCB contamination); United States v Shell Oil Co., 605 F Supp 1064 (D Colo 1985) (Rocky Mountain Arsenal)).
} 
source damages; from 1990 to 1992, the total nationwide figure was estimated at $\$ 50$ million. ${ }^{32}$ Considering that the "National Priorities List" of the United States Environmental Protection Agency ("EPA") requires cleanup of 1,296 sites (1,232 final and 64 proposed), ${ }^{33} \$ 50$ million can only be the tip of the iceberg.

What, then, explains the slow progress in using the natural resource damages provisions? One commentator has suggested that the federal government's administrative procedures encourage federal officials to focus on pursuing "cost recovery" actions, which seek reimbursement of the government's cleanup costs, instead of natural resource damages claims. ${ }^{34}$ In particular, the United States Department of the Interior ("Interior") has been slow to issue the regulations CERCLA requires concerning the assessment of natural resource damages. ${ }^{35}$ In addition, both EPA and Interior have missed opportunities either to coordinate the two types of claims successfully or to allow natural resource damages claims to proceed separately from cost recovery actions. ${ }^{36}$ As a result, "resource damage claims appear to have become an expendable chip in bargaining over cleanup settlements. ${ }^{37}$

At least one commentator has argued that the difficulty of valuing natural resources has been a major impediment to bringing these claims. ${ }^{38}$ Valuing natural resources depends directly on the problematic task of deciding which natural resource attributes society should protect. Economists separate a resource's total value into two basic components: "use" and "nonuse" values. Use values represent the resource's value to those who actually use the resource. For example, the use value of fish killed by contamination includes their value to commercial and recreational anglers. Nonuse values, in contrast, represent the value of the resource to those who have not used, and may never use, the resource. These include "existence" value-the benefit people receive from knowing that a resource (such as the Grand Canyon)

32 Thomas A. Campbell, Economic Valuation of Injury to Natural Resources, Nat Resources \& Envir 28, 28 (Winter 1992).

33 Telephone interview with Katie Daley, Environmental Protection Agency (Oct 25, 1994). See also National Priorities List, 40 CFR part 300 app B at 200-18 (1994).

${ }^{34}$ Frederick R. Anderson, Natural Resource Damages, Superfund, and the Courts, 16 BC Envir Aff 405, 415-420 (1989).

35 Id at 416. See also text accompanying notes 19-23.

${ }^{36}$ Anderson, 16 BC Envir Aff at 417-20.

37 Id at 420 .

3s See Cross, 42 Vand L Rev at 324-27 (cited in note 4) (arguing that the current lack of adequate guidance for valuing these claims must be remedied in order to accomplish the goal of the natural resource damages provisions). 
exists, even though these people never plan to visit; "option" value-the benefit people get from having the option to use a resource some time in the future; and "bequest" value-the benefit people get from knowing that their children will be able to enjoy a resource. ${ }^{39}$ Not only have economists proposed the idea of nonuse values, but courts and policymakers have also accepted the existence of these values. ${ }^{40}$

Most current methodologies for valuing natural resources, however, inadequately capture a resource's worth. Commentators have proposed a variety of measures for the value of natural resources, including the cost of restoring the resource, market valuation, and travel-cost studies. ${ }^{41}$ None of these methodologies adequately captures both use and nonuse values. For instance, economists point out that the cost of restoring a resource does not necessarily have anything to do with the value of an injury to that resource: ${ }^{42}$ under a strict cost-benefit analysis, some injuries are not worth fixing. Calculating the market value of a resource entirely misses any nonuse values that may exist and may even fail to measure use values correctly. ${ }^{43}$ Travel-cost studies (which measure the expenses people incur to visit a natural resource) encounter statistical problems ${ }^{44}$ and, like market valuation, fail to measure anything beyond use value. ${ }^{45}$

\section{Enter Contingent Valuation}

In light of the shortcomings of these more "conventional" economic techniques, the discussion of how to accurately measure natural resource damages has increasingly turned to contingent valuation. In contrast to the "indirect" methods described above, which infer the value people place on natural resources from their market behavior, contingent valuation is a "direct" method

39 Ward and Duffield, Natural Resource Damages $\$ 7.7$ at 139-40 (cited in note 6). Note that not all commentators use the same terms to describe these values. For instance, Cross calls nonuse value "existence value" and labels its subsets "vicarious value," "option value," and "intertemporal value." 42 Vand L Rev at 285-86 (cited in note 4). Cross also posits a third category of valuation called "intrinsic value"; this category represents a resource's value to the ecosystem at large, aside from its value to the public. Id at 292-97. This Comment restricts its analysis to use and nonuse values.

40 See text accompanying notes 5,52 .

41 See Cross, 42 Vand L Rev at 297-315 (cited in note 4).

42 Id at 298.

43 Id at 307-09.

44 Id at 311 .

45 Id at 313 . 
of calculating use and nonuse values. Contingent valuation is a public opinion surveying technique: surveyors ask members of a sample group how much they would be willing to pay to restore a resource to its undamaged state. ${ }^{46}$ The results are then aggregated, much as a television ratings survey would be, to provide a statistical picture of how much society as a whole values the resource in question. ${ }^{47}$

\section{Contingent valuation in regulations and case law.}

Contingent valuation became the leading methodology for valuing natural resources after the D.C. Circuit struck down Interior's first attempt to provide the valuation rules CERCLA requires. ${ }^{48}$ In two separate decisions, Ohio $v$ United States Department of the Interior and Colorado $v$ United States Department of the Interior, the court sustained states' and environmental groups' objections to Interior's rules on two grounds. ${ }^{49}$ First, the regulations contained a "lesser of" rule, which limited natural resource damages to the lesser of the cost of restoring the resource to its undamaged state or the lost use value of the resource..$^{50}$ The court held that this requirement, rooted in the approach some courts have taken when deciding common law property damage actions, failed to comply with CERCLA's preference for restoring natural resources. ${ }^{51}$ Second, the court struck down the regulations' "hierarchy" of assessment methods, which allowed trustees to calculate nonuse values only where market-

46 Ward and Duffield, Natural Resource Damages $\S 12.1$ at 282 (cited in note 6). In some surveys, people are asked how little they would accept to allow a polluter to damage the resource. One debate within the contingent valuation literature is whether the "willingness to pay" and "willingness to accept" surveys produce different results, and whether any difference has an economic explanation or is a flaw in the contingent valuation method itself. Id $\S 13.2$ at 313. See also Cross, 42 Vand L Rev at 315-19 (cited in note 4); Daniel S. Levy and David Friedman, The Revenge of the Redwoods? Reconsidering Proper. ty Rights and the Economic Allocation of Natural Resources, 61 U Chi L Rev 493, 506-15 (1994).

${ }^{47}$ Ward and Duffield, Natural Resource Damages $\S 12.8$ at 291-94 (cited in note 6).

43 CERCLA required the President to publish two regulations: one for "simplified" assessments ("Type A"), and one for larger cases requiring more extensive analysis ("Type $\mathrm{B}^{\prime \prime)}$. 42 USC $\S 9651(\mathrm{c})(2)$. The President has delegated this responsibility to Interior. See note 22. The D.C. Circuit struck down both rules in separate decisions on the same day. Ohio v United States Department of the Interior, 880 F2d 432, 481 (DC Cir 1989) (striking down "Type B" rules); Colorado v United States Department of the Interior, 880 F2d 481, 483 (DC Cir 1989) (striking down "Type $A$ " rules).

49 Ohio, 880 F2d at 481; Colorado, 880 F2d at 490 (holding that "Type A" rules suffer from the same flaws for which the Ohio court struck down the "Type $\mathrm{B}^{\text {n }}$ rules).

so Ohio, 880 F2d at $441-42$.

${ }^{61}$ Id at 459 . 
based measures of use values were unavailable. ${ }^{52}$ The court held that Interior erroneously construed CERCLA to allow trustees to recover damages only for lost use values. ${ }^{53}$ Instead, the court said, Interior should consider a rule that would allow trustees to derive a resource's value by "summing up all reliably calculated" values, including market or other estimates of use values and estimates of nonuse values such as option and existence values. $^{54}$

The Ohio court also considered industry groups' attack on contingent valuation as a means of calculating nonuse values. ${ }^{55}$ Industry groups argued that nonuse values were not compensable, that contingent valuation was "inharmonious with common law damage assessment principles," and that contingent valuation was so unreliable that its inclusion in the regulation was arbitrary and capricious. ${ }^{56}$ The court, having already rejected the notion that nonuse values were not compensable, also held that the common law prohibition on speculative damages did not apply because "the strictures of the common law" do not apply to CERCLA. ${ }^{57}$ Moreover, the court refused to find contingent valuation too unreliable for Interior's use, noting that "the risk of overestimation [of a resource's value] has not been shown to produce such egregious results as to justify judicial overruling of [Interior's] careful estimate of the caliber and worth of [contingent valuation] methodology." "58

In the wake of the Ohio and Colorado decisions, many commentators believed the D.C. Circuit had endorsed contingent valuation and thus argued that the methodology would come quickly to the fore. ${ }^{59}$ However, only one reported court decision to date has involved a natural resource damages claim in which the plaintiff-trustee attempted to prove damages through contin-

52 Id at 462-64.

53 Id at 464 .

si Id.

55 Id at 474-78. Of course, under Interior rules, contingent valuation could only be used when the preferred market-based measures were unavailable. Id at 475.

s6 Id at 476 .

s'7 Id.

ss Id at 478 .

59 See, for example, Cross, 24 U Toledo L Rev at 326 (cited in note 8) ("[T]he court's emphasis on the need to consider non-use values may virtually dictate the use of contingent valuation."); Kopp, Portney, and Smith, 20 Envir L Rptr at 10130 (cited in note 8) ("Since contingent valuation [is] the only way known to measure [ ] nonuse damages, [it] will play a key role in determining the magnitude of awards in certain cases."). 
gent valuation. In Idaho $v$ Southern Refrigerated Transport Inc., the State of Idaho sued a trucking company and the owner of a leased truck after the truck ran off a highway and spilled 375 gallons of agricultural fungicide. ${ }^{60}$ Idaho sought natural resource damages as compensation for "substantial damage [caused] to the steelhead fish population in the Little Salmon River." ${ }^{\text {61 }}$ To prove the existence value of the lost fish population and the damage to anglers caused by ending the fishing season early, Idaho introduced a contingent valuation study. ${ }^{62}$ The court found the study unpersuasive, stating that "it would be conjecture and speculation to allow damages based on this study."

While the Southern Refrigerated decision may seem to take some of the wind out of contingent valuation's sails, at least three factors limit the decision's significance. First, the contingent valuation study that Idaho proffered in Southern Refrigerated was not originally designed for the purpose of proving damages; instead, it was performed for a regional planning group to determine what people would be willing to pay, in the form of increases in their electric bills, to double the runs of fish in the entire Columbia River basin. ${ }^{64}$ Second, Idaho did not follow Interior's regulations (as none was in place after Ohio) and thus did not benefit from the "rebuttable presumption" those regulations offer trustees who follow them. ${ }^{65}$ In fact, the Southern Refrigerated court did not even refer to the regulations, the Ohio decision, or the general controversy over contingent valuation. ${ }^{66}$ Third, although Southern Refrigerated is the only reported court decision considering a contingent valuation study, few CERCLA cases ever result in a reported decision. ${ }^{67}$ Most CERCLA cases result in settlements, ${ }^{63}$ so the lack of reported cases discussing or considering contingent valuation does not diminish the technique's significance, especially in light of the debate that surrounds it.

601991 US Dist LEXIS $1869, * 1-2, * 4-6$ (D Idaho).

61 Id at $* 8$.

62 Id at $* 54-55$. Idaho also successfully sought to recover the commercial and recreational value of the killed fish, using American Fisheries Society data for the commercial value and using a travel-cost study for the recreation value. Id at $* 56-61$.

63 Id at $* 55$.

64 Id at $* 54-56$.

65 See text accompanying note 70 .

651991 US Dist LEXIS 1869 at *54-56.

${ }^{67}$ See Comment, $60 \mathrm{U}$ Chi L Rev at $705 \mathrm{n} 51$ (cited in note 14).

¿s Id at 705. 
Another indicator of contingent valuation's prominence is the fact that it remains in Interior's regulatory scheme. In March 1994, Interior finalized new "Type B" regulations to replace those struck down in Ohio. ${ }^{69}$ The new rules allow trustees to employ contingent valuation in estimating use values. ${ }^{70}$ However, Interior is still considering the role of contingent valuation in estimating nonuse values and has left temporarily intact the nonuse value language struck down in Ohio. ${ }^{71}$ As a result, five years after Ohio, the exact role contingent valuation will play in resource damage cases remains uncertain.

In addition, the National Oceanic and Atmospheric Administration ("NOAA") has been considering whether to include contingent valuation in the regulations it must issue under the Oil Pollution Act of $1990 .^{72}$ NOAA is coordinating its rule development with Interior to minimize any inconsistencies between the damage calculation methods under CERCLA and the Oil Pollution Act of $1990 .^{73}$ As a result, NOAA's recently proposed rule also includes contingent valuation. ${ }^{74}$ The combination of continued agency interest in contingent valuation with the technique's use in high-profile cases such as the Exxon Valdez litigation ${ }^{75}$ indicates that the technique is indeed the current front-runner for measuring damages in natural resource cases. However, this prominence does not come without reservations, including cautionary words from Interior. ${ }^{76}$ As a result, commentators have properly focused their attention on the strengths and weaknesses of contingent valuation.

69 Department of the Interior, Final Rule on Natural Resource Damage Assessments, 59 Fed Reg 14262 (1994).

70 Id at 14286.

71 Id at 14263.

72 See text accompanying note 4.

73 Superfund Reauthorization, 24 Envir Rptr (BNA) 1663, 1666 (1994).

74 Department of Commerce, National Oceanic and Atmospheric Administration, Notice of Proposed Rulemaking on Natural Resource Damages, 59 Fed Reg 1062, 1062 (1994).

${ }^{75}$ See Note, 105 Harv L Rev at 2000 (cited in note 9).

76 See Department of the Interior, Proposed Rule on Natural Resource Damage Assessments, 58 Fed Reg 39328, 39351 (1993) ("The potential for bias in a [contingent value] survey of nonuse values is of concern to the Department."). In addition, EPA's Science Advisory Board recently refused to endorse contingent valuation's use in a different context, that of aiding EPA in analyzing the costs and benefits of proposed regulations. Hazardous Waste: Five Reports on Corrective Action: RIA Gains Approval of SAB Executive Committee, 24 Envir Rptr (BNA) 1215, 1215 (1993). The Board did, however, urge EPA to continue studying the technique. Id. 
2. Criticisms of contingent valuation.

Although the advantage of contingent valuation is that it directly measures people's valuation of natural resources, the hypothetical nature of this measurement has led critics to argue against its use in litigation or policy-making. Proponents have responded by pointing either to empirical studies suggesting that contingent valuation's shortcomings are not as serious as critics have charged or to the absence of any better alternative.

The criticisms of contingent valuation boil down to the charge that the values being measured-for example, someone's nonuse benefit from a school of fish-are so hazy and ill defined that people's responses are much more subject to biases and variability than their responses concerning a more "tangible" good (such as toothpaste) would be. Critics have argued that survey respondents have little experience putting a price tag on natural resources and that the hypothetical nature of a contingent value survey gives them little incentive to invest the time necessary to come up with an accurate answer. ${ }^{77}$ Because survey respondents lack commitment to any particular value, they might tell the surveyor what they think she wants to hear or inflate their answer to effect a public policy for which they will not have to pay. ${ }^{78}$ Moreover, the lack of time invested in a particular response can cause the answers to vary greatly with the wording of the survey question or with the information the surveyor provides about the resource being measured. ${ }^{79}$ Perhaps most disturbingly, various experiments have shown that, regardless of the size or significance of the resource at issue, people give approximately the same answer-five to ten dollars per month-to contingent valuation surveys. ${ }^{80}$

Contingent valuation's supporters, while recognizing the theoretical danger of these biases, take issue with the claim that these problems render contingent valuation useless in practice. For instance, Professor Frank Cross, while noting problems such as strategic responses or respondents' lack of experience in valu-

77 Note, 105 Harv L Rev at 1985-86 (cited in note 9).

${ }^{78}$ Id. See also Cross, 42 Vand L Rev at 315-20 (cited in note 4) (acknowledging this possibility, but concluding that contingent valuation is the best method available for measuring use and nonuse values).

${ }^{79}$ Note, 105 Harv L Rev at 1986 (cited in note 9). In fact, if survey respondents are unaware of the natural resource in question, the information provided in the survey may actually create the nonuse values it seeks to measure. Id.

Bo Id at 1987. For example, a study showed that respondents would pay the same amount to save 2,000 birds as they would pay to save 200,000 birds. Id at $1987-88$. 
ing resources, argues that strategic behavior is "largely absent" in practice and that contingent valuation produces results similar to those of other valuation techniques. ${ }^{81}$ Kevin Ward and Professor John Duffield agree that strategic behavior "is not a major threat" to contingent valuation and argue that the technique produces results generally consistent with those of other techniques, although they concede that contingent valuation may overestimate true nonuse values to some degree. ${ }^{82}$

More fundamentally, however, contingent valuation's supporters rely on the absence of any other credible methodology to value natural resources. Cross notes that "[a]mong economic valuation tools, only contingent valuation measures the existence value of natural resources. ${ }^{983} \mathrm{He}$ also notes that indirect valuation methods not only fail to capture nonuse values but are also subject to survey biases. ${ }^{84}$ Additionally, Interior has observed that contingent valuation "is currently the only method available for the express purpose of estimating all nonuse values." ${ }^{85}$ These statements point out the fundamental weakness of the literature attacking contingent valuation: it fails to identify what policymakers, litigants, and the courts should do instead. This Comment attempts to fill this gap, not by arguing that another statistical technique would do better, but instead by suggesting that courts, agencies, and Congress should develop "rules of thumb" to decide more simply how much polluters should pay for natural resource damages. Rules of thumb would be preferable to attempts to improve contingent valuation even if they would sacrifice case-by-case accuracy.

\section{The Case against Case-By-Case Damage Determinations}

Deciding whether to invest resources in perfecting contingent valuation requires an understanding of what is at stake. To an economist, natural resource damages actions serve the same functions as tort law: to deter polluters from acting incautiously so as to cause inefficient hazardous-substance releases, and to compensate the public, as "victims," for the loss of valuable re-

\footnotetext{
st Cross, 42 Vand L Rev at 316-17 (cited in note 4).

82 Ward and Duffield, Natural Resource Damages $\S 12.9$ at 297-99, $\S 12.12$ at 309 (cited in note 6).

${ }^{3}$ Cross, 42 Vand L Rev at 320 (cited in note 4).

84 Id.

B5 59 Fed Reg at 14263 (cited in note 69).
} 
sources. To the extent that society relies on natural resource damages actions to deter pollution, it is critical that courts award damages that create an efficient level of deterrence. Is the potential extra accuracy of contingent valuation necessary to achieve that efficiency? Given the similarity in economic purpose between natural resource damages actions and tort law, examples from tort law may provide an answer to the question of whether rules of thumb or case-by-case measurement is preferable for valuing damaged resources.

A significant body of law-and-economics scholarship treats the issue of whether strict liability or negligence provides the more economically efficient way of apportioning tort liability as well as when the application of each standard is most appropriate. ${ }^{86}$ This scholarship argues that both negligence (with a defense for contributory negligence) and strict liability (for the party who could avoid an accident more cheaply) are economically efficient. ${ }^{87}$ Under a cheapest-cost-avoider strict liability standard, a court does not inquire as to the "proper" precautions a defendant should have taken to avoid an accident, and, accordingly, the court does not determine what the cost of those precautions is. ${ }^{88}$ Instead, the court holds the defendant liable so long as the defendant could have avoided the accident more cheaply than the plaintiff. Because this form of liability is just as successful as negligence-which explicitly weighs the costs and benefits of precautions-at providing the efficient amount of accident deterrence, it is possible for courts to act efficiently without ever knowing the costs of a defendant's possible precautions. ${ }^{89}$

In general, natural resource damages actions pose the opposite problem. We have no reason to believe that people are particularly unable to figure out the costs of avoiding a case of environmental contamination (the cost of installing double hulls on oil tankers, for instance, is readily ascertainable). However, unlike the torts case, we do know that people have difficulty calculating the benefits of avoiding contamination. Unfortunately, while lawand-economics scholars have argued that efficiency is possible

B6 See generally William M. Landes and Richard A. Posner, The Economic Structure of Tort Law 54-84 (Harvard, 1987); Stephen G. Gilles, Negligence, Strict Liability, and the Cheapest Cost Avoider, 78 Va L Rev 1291 (1992); Stephen G. Gilles, Rule-Based Negligence and the Regulation of Activity Levels, $21 \mathrm{~J}$ Legal Stud 319 (1992).

57 See, for example, Gilles, 78 Va L Rev at 1295-98.

83 Id at 1298.

\&9 See Landes and Posner, The Economic Structure of Tort Law at 64-65. Compare Gilles, 78 Va L Rev at 1317. 
without knowing the costs of avoiding accidents, they agree that the efficient result is generally unattainable without knowing the benefits; exposing a defendant to excessive damages will lead to excess caution, while exposing a defendant to little or no damages will result in too little or no caution. ${ }^{90}$ If the liability that courts impose on polluters is systematically too high or too low, polluters will respond by taking too many or too few precautions. ${ }^{91}$ This suggests that efficiency requires that courts hearing damages actions know the value of natural resources as accurately as possible, strengthening the case for using contingent valuation.

Despite this economic argument, this Section argues that spending resources on contingent valuation remains unproductive. First, other economic arguments counsel against contingent valuation. In particular, contingent valuation's accuracy comes at a price, and this price may outweigh the social benefits of accurate valuation. Moreover, the information costs are likely to be so high that polluters will not take the trouble to adjust their behavior before an accident, even if they know courts will use accurate valuation tools afterwards. Second, and more fundamentally, several scholars have argued that, as a theoretical proposition, the so-called nonuse value of natural resources cannot be expressed properly in monetary terms. If this is true, then spending resources on refining our estimates of nonuse values is wasteful. A refined estimate of a value that cannot be quantified is no better than a crude estimate.

\section{A. Added Efficiency vs. Information Cost}

The above discussion suggests that efficient deterrence will only exist if the law requires polluters to pay for all of the damage-including damage to nonuse values-that they do to natural resources. If natural resource damages are set too low, polluters will fail to take the socially optimal level of precautions. If damages are set too high, polluters will take some precautions that are not cost-effective. It would seem that economic reasoning

90 See, for example, Steven Shavell, Economic Analysis of Accident Law §§ 6.2.4, 6.3.1 at 130-31 (Harvard, 1987).

${ }^{91}$ Id. Optimal deterrence occurs even when courts cannot estimate damages with certainty, as long as they impose the "right" amount of damages on average. However, the problem with natural resources is precisely that traditional methods of quantifying natural resource damages systematically underestimate the true losses. 
requires us to seek every bit of precision possible in estimating natural resource damages. Thus, if contingent valuation provides unbiased estimates (at best an unsure proposition), it seems that we should insist on using the technique wherever possible.

This analysis, however, ignores the effect of information costs. If information were free, then economists would agree that courts should obtain all possible information to ensure optimal deterrence. But once we face the reality that damages information is costly and time-consuming to obtain, an economist must balance the welfare gain from optimal deterrence against the cost of the information needed to achieve that deterrence. ${ }^{92}$ To demonstrate this, assume contingent valuation provides precise estimates of the nonuse value of a natural resource; without contingent valuation, we can collect only the use value of the resource. If we forego contingent valuation, we fail to charge polluters for the full damage they do to resources; as a result, they fail to take all appropriate precautions, and a social loss results. On the other hand, if we use contingent valuation, polluters will take the right precautions, but the cost of the contingent valuation study itself is a social loss because the money spent on the study could have been used for goods and services that benefit consumers. ${ }^{93}$ Whether or not we use contingent valuation, some social loss results. The question is which social loss is greater: the cost of the study or the failure to take all cost-effective precautions.

The correct choice between contingent valuation and imprecise damages estimates is an empirical matter. As a result, one cannot say with certainty whether all precise damages calculations should be abandoned or whether in every case they should be preferred to imprecise rules of thumb. ${ }^{94}$ However, Professor Colin Diver has suggested several criteria for determining the

92 Id $\$ 6.3 .2(2)$ at 132 .

93 Contingent valuation studies are not cheap. For example, state and federal trustees have spent at least $\$ 100$ million assessing natural resource damages from the Exxon Valdez incident. Thomas A. Campbell, Natural Resource Damage Assessments: A Glance Backward and a Look Forward, 45 Baylor L Rev 221, 227, 230 (1993).

94 The choice between case-by-case and rule-bound damages calculation is a subset of the larger debate between rules and standards. Within that debate, eminent jurists, including Karl Llewellyn and Oliver Wendell Holmes, have argued fiercely for one or the other legal form as generally preferable. For a summary of this debate, including the arguments of scholars such as Chief Judge Richard Posner, Richard Epstein, and Justice Antonin Scalia, see Jason Scott Johnston, Uncertainty, Chaos, and the Torts Process: An Economic Analysis of Legal Form, 76 Cornell L Rev 341 (1991). In contrast to most participants in this debate who have argued that the law has evolved (or should evolve) toward one or the other form, Johnston argues that over time the law has oscillated between the two. 
optimal precision of rules; these criteria may illuminate how precise the damages rule for natural resources should be..$^{95}$ Diver notes that any rule (including a damages calculation rule) has three characteristics: transparency (how much room does the rule leave for adjudicative discretion?), accessibility (how hard is it to figure out what the rule is?), and congruence (does the rule substantively produce the desired behavior?). ${ }^{96}$ In measuring natural resource damages, we might say that contingent valuation is congruent-it provides the "right" estimate of damages-but also inaccessible - the cost of conducting a proper contingent valuation study is high. In contrast, a rule of thumb is accessible but incongruent.

Diver suggests that the law should minimize the social costs that occur when a rule lacks transparency, accessibility, or congruence. In particular, he outlines four objectives: (1) maximize compliance rates; (2) minimize under- and overinclusiveness; (3) minimize the costs of rule making; and (4) minimize the costs of applying a rule. ${ }^{97}$ Contingent valuation achieves the second and third objectives relatively well, at the expense of the fourth. Rules of thumb, on the other hand, achieve the fourth at the expense of the second and third. ${ }^{98}$ Contingent valuation may appear to be better at achieving the first objective, but rules of thumb may be just as effective if contingent valuation is too costly for potential polluters to replicate. How to choose? Diver argues that the law should minimize the costs of applying a rule when the rule will apply to a large number of cases, because that cost will be magnified by the large number of actors who must bear it. ${ }^{99}$ Given the vast number of environmental contamination cases, Diver's logic indicates that the law should seek to reduce the cost of applying damages rules to cases involving injuries to natural resources. As a result, it makes sense to incur the cost of developing a rule of thumb once rather than incurring the cost of preparing contingent valuation studies repeatedly.

Even if we preferred congruence to accessibility, a further economic reason exists to abandon contingent valuation. Up to

95 See Colin S. Diver, The Optimal Precision of Administrative Rules, 93 Yale L J 65, 71-76 (1983).

96 Id at 67.

97 Id at 73-74.

93 However, the speculative damages rule discussed in Section III.C. does involve low rule-making costs.

${ }^{99}$ Id at 75. 
this point, the discussion has centered on the information costs that litigants and the court system incur after an environmental accident. The discussion has assumed that, whatever damages rule is adopted, potential polluters will fully comprehend the rule and act accordingly before an accident occurs. But information costs exist even before an accident occurs. For instance, an oil shipper must decide whether to use single or double hulls on its oil tankers. ${ }^{100}$ When faced with this decision, the shipper would calculate the benefits of using a single hull (money saved) versus the costs of using a single hull (greater risk of accident multiplied by the damages a court would be likely to assess). If information is costless, the shipper's calculations will differ depending on whether the court uses contingent valuation or rules of thumb. But because information is costly, we might wonder whether the shipper will bother to nail down its expected costs precisely. In fact, even if courts use contingent valuation to value natural resources, the shipper might, for its planning purposes, use rules of thumb. In that case, the courts' costly use of contingent valuation does not change the potential polluter's behavior. ${ }^{101}$ Thus, contingent valuation wastes economic resources both because information costs outweigh any gains in efficiency and because we cannot be sure that any gains in efficiency will actually result.

100 In fact, the Oil Pollution Act of 1990 amended tanker regulation to require double hulls on most new oil tankers, taking this decision out of the hands of oil shippers. See 46 USC § 3703a (Supp 1990).

101 Indeed, a variety of studies have shown that individuals do not behave in ways that would be rational if they took into account all the relevant legal rules. See, for example, Robert C. Ellickson, A Critique of Economic and Sociological Theories of Social Control, $16 \mathrm{~J}$ Legal Stud 67, 84 (1987) (ranchers in Shasta County, California, settled injuries from wandering cattle "in almost total ignorance of their substantive legal rights"); James J. White, Contract Law in Modern Commercial Transactions, an Artifact of Twentieth Century Business Life?, 22 Washburn L J 1 (1982) (contract law did not influence how chemical companies allocated supply during shortages); H. Laurence Ross, Settled Out of Court: The Social Process of Insurance Claims 240-41 (Aldine, 1980) (automobile insurance companies settled accident cases at odds with tort law); Stewart Macaulay, NonContractual Relations in Business: A Preliminary Study, 28 Am Sociological Rev 55, 56-62 (1963) (nonlegal norms dictated behavior of firms more than legal rules). Whether information-cost considerations or noneconomic, psychological factors cause this deviation from substantive legal rules, the deviation fosters skepticism that an inaccessible legal rule will result in efficient behavior. To use Diver's terms, inaccessibility may cause incongruence. Diver, 93 Yale L J at 67-71 (cited in note 95). 
B. Incommensurability and the "Price" of Natural Resources

As noted above, the information-cost criticism of contingent valuation is empirical. In the absence of economic studies showing the social cost of assessing the wrong amount of damages, we cannot know for sure whether contingent valuation is worth the trouble. A more fundamental objection to contingent valuation, however, is that it seeks to measure something-the nonuse value of a natural resource-that cannot ever be quantified in monetary terms, no matter how precise the measurement technique.

This Comment earlier described the distinctions economists make between the use and nonuse values of natural resources. ${ }^{102}$ The term "nonuse" highlights the difficulty in measuring this aspect of value, as economists traditionally only trust valuations based on observations of individuals' "revealed preferences," that is, observations of how individuals use a good. ${ }^{103}$ But economists clearly believe that a nonuse value, such as the value one gets from knowing the Grand Canyon exists, is just like any other economic value-only more difficult to measure. Contingent valuation, of course, assumes that nonuse values are first-class, full-blooded economic values, just like the value a business derives from a machine or the value an individual places on membership in a health club.

This view, that all value is essentially the same and can be measured on the same scale, has been labelled a "monistic" theory of value. ${ }^{104}$ While monistic theories of value underlie law and economics, and many public-policy debates generally, these theories have come under increasing attack from scholars who deny that all "values should be seen as unitary,"105 and who reject the quantification of all values stated in monetary terms. ${ }^{106}$ Attempting to monetize all value, these scholars argue, does violence to the proper relationship individuals have with each other, nature, deities, and many other features of their lives. ${ }^{107}$ These

\footnotetext{
102 See text accompanying notes 38-40.

103 See Cross, 42 Vand L Rev at 315 (cited in note 4).

${ }^{104}$ See Elizabeth Anderson, Value in Ethics and Economics $\$ 6.1$ at 117 (Harvard, 1993).

${ }^{105}$ Cass R. Sunstein, Incommensurability and Valuation in Law, 92 Mich L Rev 779, 781 (1994).

${ }^{106}$ Id at 785-90.

107 Id at 785-90, 834-40; Margaret Jane Radin, Market-Inalienability, 100 Harv L Rev $1849,1905-06$ (1987).
} 
scholars suggest that the value we derive from these sources is fundamentally incommensurable with the value we derive from money and goods typically purchased with money.

As an initial proposition, this argument asserts that people perceive value in a variety of different forms. ${ }^{108}$ One of these forms is the pleasure people derive from consuming "useful" goods, and it is this relationship with goods that money measures most successfully. ${ }^{109}$ This is because useful goods can be purchased on the open market, and the difference in price between two different goods thus reflects the difference in pleasure or utility that people receive from those goods. This, however, is not the only form of value people experience. Other values-awe, love, respect-arise from people's relationships with other people and things in their environment. ${ }^{110}$ For instance, a unique natural resource such as the Grand Canyon or a rare species of bird may inspire awe and wonder in people, but they do not inspire the same strictly economic value that, say, a can of Spam does. Contrary to the claims of many economists, this observation suggests that these other values cannot be reduced to monetary terms; in other words, the different kinds of value are "incommensurable." tag on things such as human life or the Grand Canyon, the value of which is incommensurable with money. Thus, in the case of natural resource damages, there is arguably no answer to the question of how much damage pollution does to nonuse values. The values exist, but they cannot be expressed in monetary terms.

So far, however, the idea of incommensurability says nothing about what the law should be. After all, society is forced to make choices between incommensurable values all the time. ${ }^{12}$ Should we require air bags on cars? Should we require oil tankers to have double hulls to reduce the chance of oil spills? Incommensurability theory may not provide an answer to these questions, but it does not deny that these trade-offs must be made. ${ }^{113}$ It merely challenges the assertion of law and economics that these trade-offs can be made on a computer spreadsheet so long as we can discover and plug in the correct values. In-

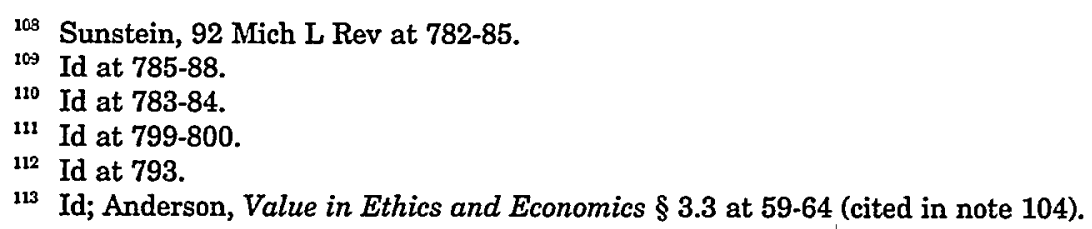


stead, incommensurability theory suggests that trade-offs must be based on noneconomic rules rather than on economic costbenefit comparisons. For instance, an economist might say it is acceptable to wipe out the spotted owl so long as the owl's extinction raises national income by a certain amount. Incommensurability theory will not permit this type of trade-off. Instead, it could be said that knowingly wiping out a species is never acceptable, unless the continued existence of a person or perhaps an entire community is at stake. This rule respects the incommensurability between the owl and money because it understands that the morality of society's dealings with the owl is dependent on nonmonetary values like people's attitudes toward the owl and the reasons why they might be willing to let it become extinct.

The problem of incommensurability suggests that contingent valuation is deeply flawed even if the needed information could be gained without cost. If the nonuse values of a natural resource are unquantifiable and incommensurable with money, even the most sophisticated calculation methods will only produce a meaningless number.

One objection to this argument is that even if it is not possible to put a price tag on nonuse values, the law should pretend that it is. ${ }^{114}$ After all, society still needs to deter polluters, express its belief that people should take care to avoid pollution, and obtain compensation for the damages that do occur. Similarly, courts award pain-and-suffering damages even though freedom from pain is surely incommensurable with money. So, perhaps contingent valuation does perform a useful function.

Two factors, however, rebut this objection and suggest that contingent valuation is at best not useful and perhaps harmful. First, to the extent that the law should fine polluters for damaging natural resources, the law should not base the level of the fines on a meaningless estimate of the "price" of the natural resources. Instead, the law should set the level of fine that will best cause polluters to conform their actions to the noneconomic rules that should govern their behavior. Second, law has an educative effect on public attitudes. ${ }^{115}$ As a result, if the law is fixated on setting the right prices for natural resources, people may eventually-and improperly-come to think of natural re-

\footnotetext{
114 See Sunstein, 92 Mich L Rev at 818-20 (cited in note 105).

115 See id at 822 .
} 
sources in monetary terms. This concern is one of "commodification": that monetary values, when encouraged by the law, tend to drive out other important, nonmonetary values. ${ }^{116}$ While this does not necessarily mean that society should avoid using damages to deter pollution, it does at least suggest that agonizing over the right measure of damages may have a harmful effect. Thus, the futility of contingent valuation is not merely a matter of empirical argument about whether a researcher can prove that the technique's costs outweigh its benefits; rather, contingent valuation is fatally flawed because it fundamentally misses the point of how trade-offs should be made between money and nature.

\section{SELECTING AN APPROPRIATE RULE OF THUMB FOR "UNMEASURABLE" NATURAL RESOURCE DAMAGES}

Although, in theory, using a rule of thumb to approximate or replace "unmeasurable" damages may better serve the economic purposes of natural resource damages law and provide the proper nonmonetized way to make trade-offs between money and nature, we cannot decide to abandon contingent valuation without knowing what particular rules of thumb might replace it. This Section reviews three possible rules of thumb, each of which has some precedent either in environmental cases or in other areas of the law. These possibilities are: (1) charging the polluter the cost of restoring the resource, without regard for whether that cost is greater than the damage done; (2) charging the polluter a fixed multiple of the measurable damages; and (3) charging the polluter according to a fixed schedule.

All of these possibilities would capture the economic advantages discussed in Section II and avoid undue obsession with assigning a "value" that cannot really be calculated. The choice among the possibilities depends in part on how close we believe each option gets, on average, to the "true" value of natural resource damages (if one exists), and on the degree to which each option protects natural resources from unnecessary commodification. In addition, the choice also depends on the relative ease or difficulty of adopting each possibility. As this Section discusses, courts could implement some options, such as the preference for restoration, through statutory interpretation of CERCLA. ${ }^{117}$

116 See Radin, 100 Harv L Rev at 1912-14 (cited in note 107).

117 In Ohio, the D.C. Circuit used statutory interpretation to conclude that Interior's 
Other options, such as implementing a fixed schedule of damages, would require congressional action.

\section{A. Option One: A "Restoration Rule"}

Understanding the first option-requiring polluters to pay the cost of restoring a resource-requires a review of how CERCLA and other statutes treat the distinction between "cleanup or removal" and "restoration." CERCLA requires polluters either to clean up and remove any hazardous substances or to reimburse the government or third parties for doing the cleanup themselves. ${ }^{118}$ "Cleanup" refers to the work necessary to remove the contaminants from the environment and remove any risk of further environmental damage. ${ }^{119}$ In contrast, "restoration" refers to actions, like repopulating a river with fish, that seek to return the ecosystem to its pre-contaminated state. CERCLA's text does not require reimbursement of costs to restore a contaminated site; instead, it provides for natural resource damages actions. ${ }^{120}$ The first possible rule of thumb, then, would be to approximate unmeasurable damages as the amount it would cost to restore a resource fully to its pre-contaminated state.

In part, restoration is already part of any natural resource damages action. At common law, the usual measure of damages to property is the lesser of the decline in the property's market value and the cost of restoring the property. ${ }^{121}$ The rationale is that, when restoration costs less than paying the decline in market value, compensating the plaintiff for the lost market value would give her a windfall: she could use the money to restore the

\footnotetext{
natural resource damages assessment regulations violated CERCLA because Congress had expressed a preference for restoration. $880 \mathrm{~F} 2 \mathrm{~d}$ at 459 . See also text accompanying notes 48-58. But the Ohio court stopped short of saying that CERCLA required use of either contingent valuation or any rule of thumb, including what this Comment calls a "restoration rule." $880 \mathrm{~F} 2 \mathrm{~d}$ at 478.

${ }_{118} 42$ USC $\S 9607(a)$. On its face, the statute only requires polluters to reimburse others' costs, but a polluter can, of course, avoid reimbursement costs by doing the work itself. The Oil Pollution Act of 1990 has a similar requirement. See 33 USC $\S 2702(b)(1)$.

11942 USC § 9601(23). See also Dan B. Dobbs, 1 Law of Remedies: Damages-EquityRestitution § 5.2(5) at 727 (West, 2d ed 1992).

${ }_{120} 42$ USC \& 9607(a). See also the Oil Pollution Act of 1990's similar provision, 33 USC $\S 2702(b)(2)$.

${ }^{121}$ See, for example, Peevyhouse v Garland Coal \& Mining Co., 382 P2d 109, 114 (Okla 1962) (preferring damages based on diminution in market value where it would be "grossly disproportionate" to award the costs of restoration).
} 
property and "keep the change."122 When restoration costs more than paying the lost market value, forcing the defendant to restore the property is inefficient: the cheaper lost-value damages would leave the plaintiff just as satisfied. ${ }^{123}$ Interior's natural resource damages regulations, struck down in Ohio, incorporated this principle and limited damages to the lesser of the lost value or the restoration cost. ${ }^{124}$

However, an examination of CERCLA's cleanup provisions reveals that restoration costs may be a good rule of thumb for approximating damages even when it is difficult to know whether restoration is cheaper than the lost resource value. As noted above, CERCLA does not require that contaminated sites be cleaned up only after a showing that cleanup is cost-effective; CERCLA always requires cleanup. One way to interpret this requirement is that Congress concluded that, on average, cleanup is cost-effective. ${ }^{125}$ Under that interpretation, Congress has replaced case-by-case decision making on whether to pay for cleanup or pay for lost value with a rule of thumb: always pay for cleanup. Likewise, a similar decision could be made on the choice between paying for restoration and paying for lost value: always pay for restoration.

Indeed, the D.C. Circuit in Ohio suggested that Congress intended just such a presumption. ${ }^{126}$ While the court did not mandate a rule requiring restoration in all cases, and while the court did not reject economic efficiency as a legitimate goal, the court did hold that "Congress established a distinct preference for restoration cost as the measure of recovery." ${ }^{\text {2127 }}$ Interior, in promulgating its new natural resource damages regulations, has accepted this view. The new rule separates a natural resource trustee's decision on how much restoration to perform from the calculation of damages. Trustees must first decide which restoration methods, if any, to use, but they are not required to use costbenefit analysis in making this decision (although the rule includes cost among the factors trustees must consider). ${ }^{128}$ Only after the restoration decision has been made does the trustee

${ }^{122}$ Dobbs, 1 Law of Remedies $\S 5.2(1)$ at 714.

${ }^{123}$ Id at 714-15.

${ }^{124}$ Ohio, 880 F2d at 441-42, citing 43 CFR $\S 11.35(b)(2)$ (1987).

${ }^{125}$ See Dobbs, 1 Law of Remedies $\$ 5.2(5)$ at 725 (cited in note 119) (suggesting that a cost-reimbursement requirement serves this purpose).

${ }^{123} 880 \mathrm{~F} 2 \mathrm{~d}$ at 459 (striking down Interior's "lesser of" rule).

127 Id.

${ }^{123} 59$ Fed Reg at 14264 (cited in note 69). 
calculate damages. Damages then include the full cost of any restoration actions taken, plus the value of any damages (including temporary damages pending restoration) that cannot be healed by the restoration actions. ${ }^{19}$

As a result, Interior has already selected a weak form of the restoration rule. Unlike the rule this Comment suggests, in which polluters would always pay for restoration, the new Interior rule only allows trustees to perform and receive compensation for full restoration. Nonetheless, this weak endorsement of a restoration rule makes such a rule of thumb simple to implement. Natural resource trustees could implement a full restoration rule themselves by adopting a standard practice of requiring full restoration even if a cost-benefit analysis would not seem to justify it.

This full restoration rule has two drawbacks, however. The first is that restoration costs may, in some cases, be grossly disproportionate to the lost resource value. One answer to this criticism is that this risk exists whenever we choose to use a rule of thumb rather than a case-by-case determination. The hope is that the efficiency gains from not calculating unmeasurable damages in each case will outweigh the occasional "wrong" decisions reached by applying the restoration rule. However, we need not rely solely on this general argument. A second response to this criticism is that we might make an exception to the restoration rule for cases where a defendant can show that restoration costs are grossly disproportionate. Under the new Interior regulation, for example, trustees are free to allow exceptions when common sense seems to require them.

A more fundamental criticism is that restoration is neither completely effective nor immediate. Even after a resource is "restored," some value remains lost wherever the restoration is not perfect. Moreover, the public loses both use and nonuse value during the time it takes to complete the restoration. A restoration rule would not compensate the public for either of these losses. Of course, calculating the lost use values may be possible using traditional damage assessment methods. However, to recover any temporary loss in nonuse value, either an additional rule of thumb would have to be adopted to approximate these losses, or any recovery through adoption of a speculative damages rule would have to be barred. ${ }^{130}$ In fact, the Interior rule

129 Id.

130 As discussed above, the Southern Refrigerated court applied the speculative dam- 
recognizes this shortcoming, defining damages to include both the cost of restoration and the value of the damage that restoration cannot cure. ${ }^{131}$ As a result, while the restoration rule should be a part of any rule of thumb for natural resource damages, it cannot be the whole solution.

\section{B. Option Two: Damages Multiplier}

The damages multiplier approach would assume, as a rule of thumb, that the total damage to a natural resource (a combination of the measurable and unmeasurable damages) equals some fixed multiplier of the measurable, market-based portion of damages. The trustee would receive the measurable damages multiplied by the multiplier. For instance, trustees might receive double or triple the measured damages. Unlike the restoration rule, the damages multiplier would avoid litigation over the best or cheapest restoration plan. But like the restoration rule, the damages multiplier would, on average, lead to awards that more closely matched the true damage done to a resource. ${ }^{132}$

A wide variety of statutes already contain damages multipliers. These statutes include consumer protection, antitrust, and trademark and patent laws, as well as statutes protecting important social and economic rights, such as rights created by labor legislation. ${ }^{133}$ The Racketeer Influenced and Corrupt Organizations Act also provides for treble damages. ${ }^{134}$ Some of these statutes multiply damages to induce private parties to act as private attorneys general in preventing harm to the general public. ${ }^{135}$ Others do so for the same reason one might use a multiplier in natural resource damages actions: "to provide a kind of

ages doctrine to deny recovery based on a contingent valuation study for any nonuse values. See text accompanying notes 60-68. Despite this precedent for replacing contingent valuation with the speculative damages doctrine, this approach is legally and politically unpalatable as a general alternative to contingent valuation. For example, the Ohio court was much more concerned that nonuse values would go uncompensated than it was that the evidence needed to prove those values might be speculative. See text accompanying notes 48-58. See also Nicoll, 5 USF Marit L J at 344 (cited in note 26) (arguing that Ohio foreclosed a speculative damages approach). Nonetheless, courts applying a restoration preference might still credibly bar recovery for temporary nonuse damages as speculative.

131 59 Fed Reg at 14264 (cited in note 69).

132 A multiplier approach is also related to the speculative damages doctrine. In fact, the speculative damages rule can be seen as a subset of the damages multiplier approach in which the multiplier is one.

133 Dobbs, 1 Law of Remedies $\$ 3.12$ at $542-43$ (cited in note 119).

134 Id. See 18 USC $\$ 1964$ (c) (1988).

135 Dobbs, 1 Law of Remedies $\S 3.12$ at 543-44 (cited in note 119). 
liquidated damages for actual losses that cannot be proved or are otherwise unrecognized by the law."136

How should an economist, or a person concerned about incommensurability, view this alternative? Law-and-economics scholars have criticized punitive damages as inefficient because punitive damages give defendants excessive incentives to take precautions. ${ }^{137}$ Moreover, while all damages multipliers are not intended to function as punishment, Professor William Landes and Chief Judge Richard Posner have criticized the use of treble damages in antitrust law, Posner arguing that "two-thirds of every antitrust damage award represents punitive damages." Landes and Posner maintain that treble damages would be efficient only if the damages multiplier were set to make up for a low chance of detecting antitrust violations. ${ }^{139}$ Regardless of whether antitrust violations are difficult to detect, it is probably true that damage to a valuable natural resource is not very difficult to detect. But, while this criticism may be apt in the antitrust arena, where the damages multiplier is not meant to act as a rule of thumb to better estimate actual damages, it poses no barrier in the natural resource context, where the damages multiplier does help approximate unmeasurable damages. As long as the multiplier accurately captures the unmeasurable damages on average, a damages multiplier is efficient. ${ }^{140}$

Even if one rejects the economic approach and prefers not to monetize valuations of natural resources, a damages multiplier is attractive for two reasons. First, it does not engage trustees and the courts in a futile effort to calculate something that cannot be calculated. Second, despite its simplicity, a damages multiplier still imposes a heavy sanction on polluters, communicating society's condemnation of trading natural resources for monetary gain.

\footnotetext{
136 Id $\S 3.12$ at 543, citing United States $v$ Bornstein, 423 US 303 (1976).

${ }^{137}$ Thomas C. Galligan, Jr., Augmented Awards: The Efficient Evolution of Punitive Damages, 51 La L Rev 3, 37 \& n 133 (1990).

${ }_{133}$ Richard A. Posner, Economic Analysis of Law § 10.12 at 315 (Little, Brown, 4th ed 1992).

${ }^{139}$ See id at 315-16; William M. Landes, Optimal Sanctions for Antitrust Violations, 50 U Chi L Rev 652, 653-57 (1983).

${ }^{140}$ Galligan, in fact, argues that damages multipliers could be used in many common law tort situations to correct inefficiencies caused, in part, by the tort system's failure to compensate plaintiffs for all injuries suffered in an accident. $51 \mathrm{La} \mathrm{L} \mathrm{Rev} \mathrm{at} 53$ (cited in note 137).
} 
Unlike the restoration rule, however, neither government trustees nor courts hearing natural resource damages cases can implement a damages multiplier on their own. Perhaps Interior could have implemented a multiplier approach through CERCLA's natural resource damages regulations by finding damages multipliers the "most reliable" method of calculating unmeasurable damages. Any regulations containing a damages multiplier, however, would have to gain approval from the D.C. Circuit, a court which, in Ohio, was suspicious that Interior was trying to dilute recovery rather than faithfully seeking the correct level of damages. ${ }^{141}$ The more certain method of implementing a damages multiplier would be to include it in the CERCLA reauthorization bill that Congress is expected to act upon in the near future. ${ }^{142}$ However, the Clinton Administration's proposed Superfund Reform Act of 1994 contained no amendments to CERCLA's natural resource damages provisions, ${ }^{143}$ and even if Congress added a damages multiplier to CERCLA, other environmental statutes, like the Oil Pollution Act of 1990, would still lack a multiplier.

More fundamentally, for much the same reason that it is difficult to calculate the unmeasurable damages in a particular case, it is unclear how large the damages multiplier should be. No basis currently exists for choosing any particular value for the multiplier. Before Congress or Interior is likely to implement a damages multiplier, both are likely to insist that empirical work be done to suggest an appropriate value. As a result, a multiplier approach has promise for solving the problems of contingent valuation, but does not appear likely to emerge as a commonly used rule of thumb.

\section{Option Three: Creating a Damage "Matrix"}

The State of Washington has recently pioneered another possible rule of thumb: a damage "matrix" approach modelled on workers' compensation statutes. As in workers' compensation, a damage matrix approach isolates a relatively small number of factors that determine the damage a hazardous-substance release does to a natural resource. An agency then constructs a matrix that sets a single damage figure for all contamination incidents

141 See text accompanying notes 48-58.

142 See note 12.

143 See Steven W. Jawetz, The Superfund Reform Act of 1994: Success or Failure Is Within EPA's Sole Discretion, 24 Envir L Rptr 10161, 10164-66 (1994). 
that share the same combination of factors. Like a damages multiplier, a damage matrix might bridge the gap between the simplicity of ignoring damages to nonuse values and the realism of the restoration rule. However, while the damages multiplier favors the value of simplicity, the damage matrix leans more toward the complexity of realism.

The Washington rule, which applies only to oil spills, classifies spills according to the amount of oil released, the characteristics (such as toxicity) of the oil, the geographic "zone" of the state contaminated, and the season. ${ }^{144}$ Separate matrices are used for each type of resource contaminated-including various types of habitats, fish and wildlife, and recreational areas. ${ }^{145}$ The dollar figures generated by these matrices are then adjusted to give spillers credits for cleanup activity and efforts to minimize the damage done to natural resources. ${ }^{146}$

At least one veteran of natural resource damages policy, former Assistant U.S. Attorney General Richard Stewart, has proposed that federal law adopt the damage matrix approach. ${ }^{147}$ As Stewart has observed, a damage matrix, like other rules of thumb, would reduce the time and expense required to resolve a natural resource damages case. Moreover, an economist should applaud a matrix approach because it is the richest and most accurate of the three rules of thumb. Regulators devising the matrix could be sure to place the most important variables into the matrix, thereby tailoring it to a variety of situations. As a result, the matrix approach would create incentives for potential polluters that most closely approximate the presumably correct incentives produced by an accurate contingent valuation survey-incentive effects that, as argued in Section II, we cannot otherwise afford to produce.

The matrix approach, like any of the three rules of thumb, also properly respects the incommensurability between money and natural resources because it does not require trustees to measure the value of resources on a case-by-case basis. Instead, trustees need only catalogue the existence of easily verifiable attributes (such as season of the year or type of environment

\footnotetext{
144 Wash Admin Code § 173-183-330 (1992).

145 See Washington: Ecology Department Proposes Method for Assessing Damages from Oil Spills, 22 Envir Rptr (BNA) 1841, 1841-42 (1991).

146 Id.

147 See General Policy: Workers' Compensation Model Would Improve 'Flawed' Resource Damage Scheme, Stewart Says, 22 Envir Rptr (BNA) 2145, 2145-46 (1992).
} 
affected) and look up an appropriate penalty for the polluter. While the economist may see the attributes in the matrix as proxies for the calculation a contingent valuation study would produce, someone concerned with incommensurability would view the attributes as factors that loosely dictate the seriousness with which society should condemn the destruction of any particular resource. Indeed, someone concerned with incommensurability might place different attributes in the matrix than those an economist would choose. An economist might choose attributes like acreage affected or toxicity of the substance released. A noneconomist might base the polluter's penalty on the uniqueness or beauty of the resource or even the attitude the polluter expressed toward the resource (for example, whether the pollution was unavoidable, caused by negligence, or intentional).

On the other hand, a damage matrix would require significant up-front investments that would at least partially offset the efficiency gained in subsequent cases. Moreover, just as the lack of information on the relationship between measurable and unmeasurable damages hinders efforts to craft a nonarbitrary damages multiplier, a similar information gap might endanger the credibility of any damage matrix. To someone concerned with incommensurability, however, this is a less serious problem, as there are no "correct" values to place in the matrix.

Despite the up-front costs of a matrix approach, the approach is promising as a means of reducing the time and cost of litigation in individual natural resource damages cases. In fact, a standard schedule of damages might make calculating natural resource damages the easiest part of prosecuting a Clean Water Act, Oil Pollution Act of 1990, or CERCLA case. As a result, Congress and federal agencies should strongly consider the matrix approach as part of any effort to make natural resource damages actions a more desirable alternative.

\section{CONCLUSION}

No completely satisfactory answer exists to the problem of how to "price" a publicly owned natural resource. Market-based valuation clearly fails to capture the full value of a resource to the public. As both courts and commentators have recognized, the public values natural resources for more than their usefulness; a resource's value includes nonuse values like the satisfaction of knowing a beautiful environment exists or of passing that beauty on to the next generation. Various indirect techniques also fail to capture these nonuse values. As a result, many have turned to 
contingent valuation, hoping, despite the harsh criticism that some have levelled, that contingent valuation can be perfected into an accurate, cost-effective way to capture these otherwise unmeasurable values.

This hope is misplaced, not only because contingent valuation is currently unreliable and perhaps biased, but also because contingent valuation is not worth the time and money required both to perfect the method and to litigate individual cases using it. More fundamentally, contingent valuation may be trying to monetize values that simply cannot be reduced to a quantifiable sum of money. As a result, contingent valuation should be replaced with simpler rules of thumb, which would provide quicker and cheaper resolution to individual natural resource damages cases without significantly skewing the incentives environmental law seeks to place on potential polluters.

This Comment has sought to suggest three possible rules of thumb without necessarily embracing any one possibility as perfect. However, it seems most promising that trustees should generally charge polluters with the cost of restoring a resource, perhaps unless common sense proves restoration grossly disproportionate to the resource's possible value. As a promising way of compensating trustees for the nonuse values that are still lost because restoration is neither immediate nor completely effective, Congress and federal regulatory agencies should consider codifying a matrix based on easily identifiable criteria. 